\title{
Markers of early renal changes induced by industrial pollutants. III Application to workers exposed to cadmium
}

\author{
H Roels, A M Bernard, A Cárdenas, J P Buchet, R R Lauwerys, G Hotter, I Ramis, A Mutti, \\ I Franchini, I Bundschuh, H Stolte, M E De Broe, G D Nuyts, S A Taylor, R G Price
}

\begin{abstract}
Cadmium (Cd) was the third heavy metal investigated in the European collaborative research project on the development and validation of new markers of nephrotoxicity. Fifty workers exposed to $\mathrm{Cd}$ and 50 control workers were examined. After application of selection criteria 37 workers (mean age 43) exposed to $\mathrm{Cd}$ for an average of 11.3 years; and 43 age matched referents were retained for final analysis. The average concentrations of $\mathrm{Cd}$ in blood (Cd-B) and urine (Cd-U) of exposed workers were $5.5 \mu \mathrm{g} \mathrm{Cd} / 1$ and $5.4 \mu \mathrm{g} \mathrm{Cd} / \mathrm{g}$ creatinine respectively. By contrast with lead and mercury, Cd had a broad spectrum of effects on the kidney, producing significant alterations in amounts of almost all potential indicators of nephrotoxicity that were measured in urine-namely, low and high molecular weight proteins, kidney derived antigens or enzymes, prostanoids, and various other biochemical indices such as glycosaminoglycans and sialic acid. An increase in $\beta_{2}-$ microglobulin and a decrease of sialic acid
\end{abstract}

\footnotetext{
Unité de Toxicologie Industrielle et Médecine du Travail, Faculté de Médecine, Université Catholique de Louvain

H Roels, A M Bernard, A Cárdenas, J P Buchet, R Lauwerys

Departamento de Neuroquimica, Laboratorio de Eicosanoides, CID-CSIC, Barcelona, Spain

I Ramis, G Hotter

Laboratorio di Tossicologia Industriale, Università degli Studi di Parma, Parma, Italy

A Mutti, I Franchini

Abteilung für Nephrologie, Medizinische Hochschule Hannover, Hannover, Germany

I Bundschuh, $\mathrm{H}$ Stolte

Department of Nephrology-Hypertension, University of Antwerp, Edegem-Antwerp, Belgium

$M$ E De Broe, G D Nuyts

Biochemistry Section, Biomolecular Sciences, King's College, London, United Kingdom S A Taylor, R G Price
}

concentration were found in serum. Doseeffect/response relations could be established between most of these markers and Cd-U or Cd-B. The thresholds of $\mathrm{Cd}-\mathrm{U}$ associated with a significantly higher probability of change in these indicators were estimated by logistic regression analysis. Three main groups of thresholds could be identified: one around $2 \mu \mathrm{g} \mathrm{Cd} / \mathrm{g}$ creatinine mainly associated with biochemical alterations, a second around $4 \mu \mathrm{g} \mathrm{Cd} / \mathrm{g}$ creatinine for high molecular weight proteins and some tubular antigens or enzymes, and a third one around $10 \mu \mathrm{g} \mathrm{Cd} / \mathrm{g}$ creatinine for low molecular weight proteins and other indicators. The recent recommendation by the American Conference of Governmental Industrial Hygienists (ACGIH) of $5 \mu \mathrm{g} \mathrm{Cd} / \mathrm{g}$ creatinine in urine as the biological exposure limit for occupational exposure to $\mathrm{Cd}$ appears thus justified, although for most of the effects occurring around this threshold the link with the subsequent development of overt $\mathrm{Cd}$ nephropathy is not established. In that respect, the very early interference with production of some prostanoids (threshold $2 \mu \mathrm{g} \mathrm{Cd} / \mathrm{g}$ creatinine) deserves further investigation; although this effect might contribute to protect the filtration capacity of the kidneys, it might also play a part in the toxicity of $\mathrm{Cd}$ on bone.

(British Journal of Industrial Medicine 1993;50:37-48)

The kidney is the critical organ after long term occupational or environmental exposure to cadmium (Cd). Since the first description by Friberg, ${ }^{1}$ of chronic Cd nephropathy, numerous epidemiological studies on industrial workers or on inhabitants of $\mathrm{Cd}$ polluted areas have documented the constellation of renal effects that may be produced by this heavy metal. As reviewed elsewhere ${ }^{2-4}$ the nephrotoxic action of $\mathrm{Cd}$ can be detected on the basis of various urinary (low and high molecular weight proteins, enzymes, tubular antigens) or bloodborne (serum $\beta_{2^{-}}$ microglobulin $\left(\beta_{2}-\mathrm{m}\right)$ or creatinine) markers. Several 
of these markers have been used to assess the concentration of $\mathrm{Cd}$ in kidney or urine associated with a risk of renal dysfunction. The critical concentrations vary with the selected renal effect. For instance the concentrations of $\mathrm{Cd}$ in urine (Cd-U) associated with a $10 \%$ risk of increased enzymuria or microproteinuria vary from about 5 to $10 \mu \mathrm{g} / \mathrm{g}$ creatinine..$^{2-5}$ The average concentrations of $\mathrm{Cd}$ in the kidney cortex corresponding to these values are 100 200 ppm. $^{6-10}$

Cadmium is also presently the only industrial nephrotoxic chemical for which early indicators of toxicity have been validated. Follow up studies in workers exposed to $\mathrm{Cd}$ have clearly shown that the appearance of a persistent microproteinuria is the forerunner of a progressive deterioration of renal function. $^{1112}$

The selection of $\mathrm{Cd}$ in the framework of the European Community research project on the development and validation of new indicators of nephrotoxicity was of particular interest from more than one point of view. Firstly, because $\mathrm{Cd}$ is a well established nephrotoxin, affecting most of the markers examined in this project, the study presented a unique opportunity to compare the relative sensitivity of markers that have rarely been analysed in combination. Secondly, the application of a comprehensive battery of sensitive markers of nephrotoxicity may help to resolve the current controversy as to whether the critical concentration of $\mathrm{Cd}-\mathrm{U}$ is closer to $10 \mu \mathrm{g} / \mathrm{g}$ creatinine as suggested by earlier studies mainly based on increased urinary excretion of low molecular weight proteins ${ }^{13-15}$ or to $5 \mu \mathrm{g} / \mathrm{g}$ creatinine as proposed by more recent studies. ${ }^{16-18}$ Finally, the determination of urinary prostaglandin concentration might provide insight into mechanisms in the progression of $\mathrm{Cd}$ nephropathy.

\section{Subjects and methods \\ STUDY POPULATION}

The study was conducted on 100 male workers recruited from two primary zinc and cadmium smelters in Belgium. The cohort of exposed workers included 40 subjects who were currently $(n=35)$ or previously ( $n=5$ ) employed in the Cd refinery departments of these plants and 10 workers who had been occupied until the early 1970s at horizontal retort zinc furnaces for the reduction of zinc calcine with coal. All the $\mathrm{Cd}$ workers had a $\mathrm{Cd}-\mathrm{U}$ higher than $2 \mu \mathrm{g} / \mathrm{g}$ creatinine and had been exposed to $\mathrm{Cd}$ for at least one year (range $1 \cdot 1$ to 36.4 years). The occupational exposure to $\mathrm{Cd}$ ceased on average 11 (range 1-22) and 17 (range 15-19) years ago for the five $\mathrm{Cd}$ refinery and the 10 zinc furnace workers respectively. The control workers were recruited from the same plant but in departments where occupational exposure to heavy metals (Cd, lead, mercury) did not occur.

As in the two previous studies ${ }^{1920}$ a careful selection of the workers was made to exclude subjects whose renal function might be altered by causes other than exposure to $\mathrm{Cd}$. In particular, it was ascertained that all control or exposed workers had a blood lead concentration below $350 \mu \mathrm{g} / 1$ and a concentration of mercury in urine lower than $5 \mu \mathrm{g} / \mathrm{g}$ creatinine, and that control workers had a Cd-U below $2 \mu \mathrm{g} / \mathrm{g}$ creatinine. Also, the results obtained on urine sam-

Table 1 Characteristics of control and cadmium exposed workers

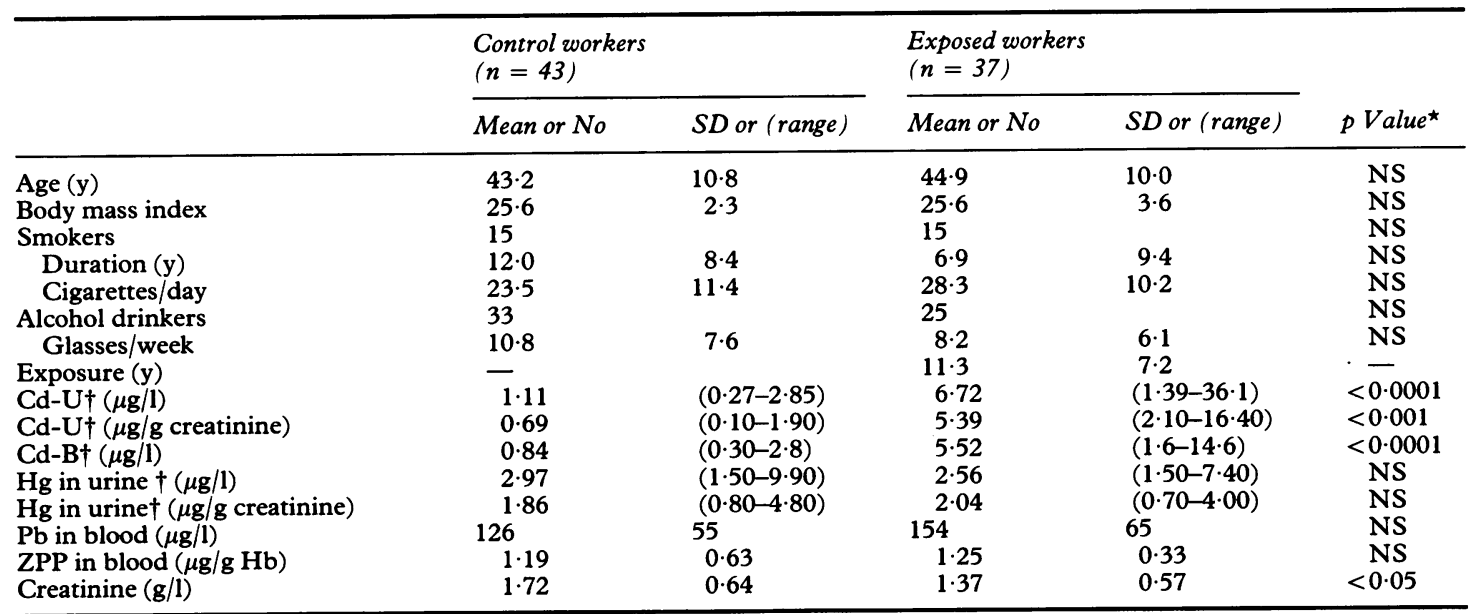

^Student's $t$ test or $\chi^{2}$ test.

†Geometric means. 
Table 2 Significant associations found by multiple regression analysis

\begin{tabular}{|c|c|c|c|c|}
\hline Dependent variables ${ }^{\star}$ & $\begin{array}{l}\text { Independent } \\
\text { variables }\end{array}$ & $\begin{array}{l}\text { Partial } \\
\text { regression } \\
\text { coefficient }\end{array}$ & Partial $r^{2}$ & p Value \\
\hline \multicolumn{5}{|l|}{ Urine: } \\
\hline Albumin + & Crt-U & 0.837 & $0 \cdot 228$ & 0.0001 \\
\hline \multirow{2}{*}{ Transferrin $t_{+}^{+}$} & $\begin{array}{l}\text { Cd-U } \\
\text { Crt-U }\end{array}$ & $\begin{array}{l}0.211 \\
0.869\end{array}$ & $\begin{array}{l}0.081 \\
0.168\end{array}$ & $\begin{array}{l}0.0037 \\
0.0002\end{array}$ \\
\hline & $\mathrm{Cd}-\mathrm{U}$ & $0 \cdot 265$ & 0.084 & 0.0042 \\
\hline \multirow[t]{2}{*}{$\mathrm{IgG}_{+}^{+}$} & Crt-U & 1.031 & $0 \cdot 272$ & 0.0001 \\
\hline & Drinker & $-0 \cdot 179$ & 0.043 & 0.0306 \\
\hline$\beta_{2} \mathrm{~m}_{+}^{+}$ & Cd-U & 0.280 & $0 \cdot 109$ & 0.0029 \\
\hline \multirow[t]{2}{*}{$\mathrm{RBP}_{+}^{+}$} & Crt-U & 0.773 & $0 \cdot 195$ & 0.0001 \\
\hline & Drinker & $-0 \cdot 180$ & 0.055 & 0.0195 \\
\hline \multirow[t]{2}{*}{ Protein $1 \dagger$} & Crt-U & $1 \cdot 027$ & $0 \cdot 241$ & 0.0001 \\
\hline & Smoker & -0.173 & 0.039 & 0.0443 \\
\hline \multirow[t]{2}{*}{ THG } & Crt-U & 0.879 & 0.351 & 0.0001 \\
\hline & $\mathrm{Cd}-\mathrm{U}$ & $0 \cdot 127$ & 0.043 & 0.0220 \\
\hline \multirow[t]{2}{*}{$\mathrm{NAG}_{+}^{+}$} & Crt-U & 0.642 & $0 \cdot 283$ & 0.0001 \\
\hline & $\mathrm{Cd}-\mathrm{U}$ & $0 \cdot 164$ & $0 \cdot 103$ & 0.0006 \\
\hline \multirow[t]{2}{*}{ BB50† } & Crt-U & 0.618 & $0 \cdot 145$ & 0.0005 \\
\hline & $\mathrm{Cd}-\mathrm{U}$ & $0 \cdot 150$ & 0.048 & 0.0358 \\
\hline \multirow[t]{2}{*}{ BBA } & $\mathrm{Cd}-\mathrm{U}$ & $0 \cdot 183$ & $0 \cdot 109$ & 0.0028 \\
\hline & Crt-U & 0.400 & 0.066 & 0.0151 \\
\hline \multirow[t]{3}{*}{ HF5 } & Crt-U & 0.392 & 0.093 & 0.0061 \\
\hline & $\mathrm{Cd}-\mathrm{U}$ & $0 \cdot 141$ & 0.063 & $0 \cdot 0188$ \\
\hline & Crt-U & 0.670 & 0.098 & 0.0010 \\
\hline \multirow[t]{2}{*}{$\mathrm{IAP}_{+}^{+}$} & $\mathrm{Cd}-\mathrm{U}$ & 0.366 & $0 \cdot 251$ & 0.0001 \\
\hline & Body mass index & 0.028 & 0.035 & 0.0410 \\
\hline TNAP & Crt-U & $1 \cdot 111$ & $0 \cdot 161$ & 0.0002 \\
\hline \multirow[t]{2}{*}{ Fibronectin } & Crt-U & 0.452 & 0.092 & 0.0062 \\
\hline & Smoker & $0 \cdot 126$ & 0.049 & 0.0392 \\
\hline \multirow[t]{2}{*}{ 6-keto-PGF ${ }_{1 x}$} & Crt-U & 0.787 & 0.333 & 0.0001 \\
\hline & Cd-B & $0 \cdot 175$ & $0 \cdot 122$ & 0.0001 \\
\hline \multirow[t]{2}{*}{$\mathrm{PGE}_{2}$} & $\mathrm{Crt}-\mathrm{U}$ & 0.790 & $0 \cdot 207$ & 0.0001 \\
\hline & Cd-B & $0 \cdot 252$ & 0.159 & 0.0001 \\
\hline $\mathrm{PGF}_{2 x}$ & Crt-U & $1 \cdot 307$ & 0.385 & 0.0001 \\
\hline $\mathrm{TXB}_{2}$ & Crt-U & 0.608 & 0.253 & 0.0001 \\
\hline Kallikrein & Crt-U & $0 \cdot 818$ & 0.275 & 0.0001 \\
\hline \multirow[t]{3}{*}{ GAG } & Crt-U & 0.648 & 0.707 & 0.0001 \\
\hline & Cd-U & 0.040 & 0.023 & 0.0118 \\
\hline & Drinker & -0.043 & 0.015 & 0.0357 \\
\hline \multirow[t]{2}{*}{ Sialic acid } & Crt-U & 1.007 & 0.760 & 0.0001 \\
\hline & Cd-B & 0.095 & 0.040 & 0.0002 \\
\hline \multicolumn{5}{|l|}{ Blood: } \\
\hline Creatinine/serum $\dagger$ & Smoker & -0.522 & 0.059 & 0.0294 \\
\hline$\beta_{2}-\mathrm{m} /$ serum ++ & Cd-U & 0.375 & $0 \cdot 185$ & 0.0001 \\
\hline Sialic acid/plasma $\dagger$ & Cd-B & $-42 \cdot 02$ & 0.062 & 0.0261 \\
\hline Sialic acid/RBC & Cd-U & $-1 \cdot 276$ & 0.054 & 0.0378 \\
\hline
\end{tabular}

*All urinary variables (expressed per litre of urine) and Cd-B were log transformed.

† Standardised for age.

†Associated to duration of exposure in the exposed group. For abbreviations see subjects and methods section.

ples with a creatinine concentration lower than 0.3 or higher than $4 \mathrm{~g} / 1$ were discarded and for the assay of kallikrein, those obtained in subjects with a natriuria lower than $35 \mathrm{mmol} / \mathrm{g}$ creatinine were excluded as well. After that selection, 37 workers were retained in the Cd cohort (26 currently and 11 previously exposed) and 43 in the control cohort.

\section{Methods}

The collection of biological samples was according to the protocol in the two previous studies. ${ }^{1920}$ The battery of tests was almost identical, comprising, in blood: lead, cadmium (Cd-B) and zinc protoporphyrin (ZPP) concentrations, alcian blue (AB) binding to red blood cell (RBC) surfaces, sialic acid content of RBC membranes; in serum or plasma: creatinine (crt-S), $\beta_{2}-\mathrm{m}$, sialic acid, antiglomerular basement membrane antibodies (anti-GBM); and in urine:Cd-U, mercury $(\mathrm{Hg}-\mathrm{U})$, sodium, creatinine (crt-U), pH, albumin, transferrin, immunoglobulin (IgG), $\beta_{2}-\mathrm{m}$, retinol binding protein (RBP), protein 
Table 3 Urinary and bloodborne markers of nephrotoxicity in controls and workers exposed to Cd

\begin{tabular}{|c|c|c|c|}
\hline Marker & $\begin{array}{l}\text { Control workers } \\
(n=43) \S \\
\text { Mean (SD or range) }\end{array}$ & $\begin{array}{l}\text { Exposed workers } \\
(n=37) \mid \\
\text { Mean (SD or range) }\end{array}$ & $p$ Value $^{\star}$ \\
\hline 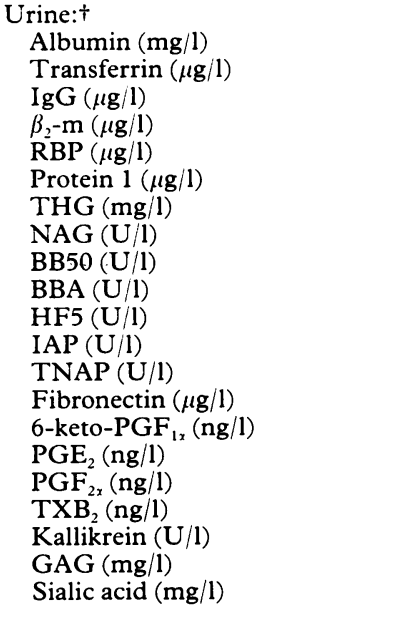 & $\begin{array}{c}8 \cdot 3(3 \cdot 7-40 \cdot 0) \\
271(68-2464) \\
1850(381-11313) \\
76(9-440) \\
83(27-608) \\
123(33-609) \\
24 \cdot 9(6 \cdot 0-66 \cdot 4) \\
1 \cdot 32(0 \cdot 20-2 \cdot 70) \\
4 \cdot 2(0 \cdot 8-17 \cdot 2) \\
3 \cdot 7(0 \cdot 9-24 \cdot 4) \\
5 \cdot 8(2 \cdot 4-17 \cdot 8) \\
0 \cdot 86(0 \cdot 19-4 \cdot 9) \\
0 \cdot 272(0 \cdot 012-2 \cdot 38) \\
15 \cdot 3(4 \cdot 0-103) \\
165(37-322) \\
216(85-548) \\
337(108-1803) \\
66(2-235) \\
0 \cdot 72(0 \cdot 20-3 \cdot 17) \\
45 \cdot 2(33 \cdot 4-83 \cdot 3) \\
355(238-472)\end{array}$ & $\begin{array}{c}11 \cdot 1(3 \cdot 8-198) \\
471(72-8429) \\
1764(499-9432) \\
112(19-5508) \\
94(34-2737) \\
134(15-3566) \\
31 \cdot 5(9 \cdot 8-160) \\
1 \cdot 62(0 \cdot 70-5 \cdot 91) \\
6 \cdot 1(1 \cdot 7-91 \cdot 4) \\
5 \cdot 3(1 \cdot 8-108 \cdot 9) \\
7 \cdot 4(1 \cdot 7-133) \\
1 \cdot 53(0 \cdot 26-13 \cdot 1) \\
0 \cdot 403(0 \cdot 008-3 \cdot 48) \\
15 \cdot 0(3 \cdot 6-37 \cdot 8) \\
243(75-438) \\
329(97-947) \\
353(31-1308) \\
68(22-186) \\
0 \cdot 82(0 \cdot 22-1 \cdot 86) \\
47 \cdot 9(25 \cdot 0-86 \cdot 6) \\
425(243-878)\end{array}$ & $\begin{array}{l}\text { NS } \\
<0 \cdot 01 \\
\text { NS } \\
\text { NS } \\
\text { NS } \\
\text { NS } \\
\text { NS } \\
\text { NS } \\
<0 \cdot 05 \\
<0 \cdot 05 \\
\text { NS } \\
<0 \cdot 01 \\
\text { NS } \\
\text { NS } \\
<0 \cdot 00001 \\
<0 \cdot 01 \\
\text { NS } \\
\text { NS } \\
\text { NS } \\
\text { NS } \\
<0 \cdot 001\end{array}$ \\
\hline $\begin{array}{l}\text { Blood: }{ }_{+}^{+} \\
\text {Creatinine/serum (mg/l) } \\
\beta_{2}-\mathrm{m} / \text { serum }(\mathrm{mg} / \mathrm{l}) \\
\text { Sialic acid/plasma }(\mathrm{mg} / \mathrm{l}) \\
\text { Sialic acid/RBC }(\mu \mathrm{g} / \mathrm{mg} \text { protein }) \\
\text { AB binding/RBC }\left(\mathrm{ng} / 10^{6} \mathrm{RBC}\right) \\
\text { Anti-GBM/serum }(\mathrm{U} / \mathrm{l})\end{array}$ & $\begin{array}{c}10 \cdot 3(1 \cdot 0) \\
1 \cdot 39(0 \cdot 39) \\
629(79) \\
25 \cdot 7(2 \cdot 7) \\
197(15) \\
25 \cdot 4(7 \cdot 4)\end{array}$ & $\begin{array}{c}9 \cdot 8(1 \cdot 0) \\
1 \cdot 75(0 \cdot 41) \\
600(109) \\
24 \cdot 9(2 \cdot 7) \\
191(19) \\
23.9(7 \cdot 0)\end{array}$ & $\begin{array}{l}<0.05 \\
<0.001 \\
\text { NS } \\
\text { NS } \\
\text { NS } \\
\text { NS }\end{array}$ \\
\hline
\end{tabular}

* Student's $t$ test.

†Geometric means; ${ }_{+}^{+}$Arithmetic means.

$\S$ For $\mathrm{PGE}_{2}$ and kallikrein $\mathrm{n}=39$.

For $\mathrm{PGE}_{2} \mathrm{n}=35$.

For the abbreviations see subjects and methods section.

All the markers of nephrotoxicity were standardised for the determinants unrelated to Cd exposure (see table 2). Standardisation was based on the mean of the total population.

1, Tamm-Horsfall glycoprotein (THG), fibronectin, 6-keto-prostaglandin $F_{1 x}$ (6-keto-PGF $F_{1 x}$ ), prostaglandin $\mathrm{E}_{2}\left(\mathrm{PGE}_{2}\right)$, prostaglandin $\mathrm{F}_{2 x}\left(\mathrm{PGF}_{2 x}\right)$, thromboxane $\mathrm{B}_{2}\left(\mathrm{TXB}_{2}\right)$, sialic acid, glycosaminoglycans (GAG), the BBA, BB50, and HF5 brush border antigens, and the activities of kallikrein, intestinal alkaline phosphatase (IAP), tissue nonspecific alkaline phosphatase (TNAP), and $\mathrm{N}$-acetyl$\beta$-D-glucosaminidase (NAG).

Statistical analysis was performed as described earlier. ${ }^{19}$

\section{Results}

Table 1 outlines the general characteristics and exposure parameters of workers exposed to $\mathrm{Cd}$ and their controls. No significant differences were found between the two cohorts for age, body mass index, smoking and drinking habits, or exposure to lead or mercury. The mean crt- $U$ was slightly lower in exposed workers. By contrast Cd-U or Cd-B were on the average six to eight times higher than those of the control group. The mean duration of exposure was 11.3 years.

In the control group, the urinary excretion of transferrin, protein 1 , and BB50, and also crt-S (serum) and sialic acid concentration in plasma showed a positive association with age. Multivariate correlation analysis was performed on the whole population $(n=80)$ after standardisation of these five variables for age. Table 2 lists the determinants significantly associated with the dependent variables. When associations were found with both Cd-B and Cd-U (tested separately), however, only the strongest one is mentioned in this table. All urinary parameters, except $\beta_{2}-\mathrm{m}$, were positively correlated with crt-U. Significant positive associations were found between $C d-U$ and concentrations of albumin, transferrin, $\beta_{2}-\mathrm{m}, \mathrm{NAG}, \mathrm{GAG}$, and most tubular antigens (THG, BB50, BBA, HF5, and IAP). 
Table 4 Prevalences of abnormal values of urinary and bloodborne markers of nephrotoxicity in controls and workers exposed to $C d$

\begin{tabular}{|c|c|c|c|c|c|c|}
\hline Marker & Cut off value ${ }^{\dagger}$ & $\begin{array}{l}\text { Con } \\
\text { (n }= \\
\text { No }\end{array}$ & $\begin{array}{l}\text { rol workers } \\
43)_{+}^{ \pm} \\
(\%)\end{array}$ & $\begin{array}{l}\operatorname{Exp} \\
(n \\
\text { No }\end{array}$ & $\begin{array}{l}\text { ed workers } \\
37) \S \\
(\%)\end{array}$ & p Value \\
\hline $\begin{array}{l}\text { Urine: } \\
\text { Albumin } \\
\text { Transferrin } \\
\text { IgG } \\
\beta_{2} \text {-m } \\
\text { RBP } \\
\text { Protein } 1 \\
\text { THG } \\
\text { NAG } \\
\text { BB50 } \\
\text { BBA } \\
\text { HF5 } \\
\text { IAP } \\
\text { TNAP } \\
\text { Fibronectin } \\
\text { 6-keto-PGF } \\
\text { PGE } \\
\text { PGF } \\
\text { TX } \\
\text { TXB } \\
\text { Kallikrein }_{\text {GAG }} \\
\text { GAGic acid }_{\text {Sialic }}\end{array}$ & $\begin{array}{l}>19 \cdot 0 \\
>903 \\
>5042 \\
>279 \\
>184 \\
>340 \\
>50 \cdot 1 \\
>2 \cdot 19 \\
>15 \cdot 6 \\
>6 \cdot 7 \\
>12 \cdot 6 \\
>2 \cdot 72 \\
>1 \cdot 137 \\
>41 \cdot 7 \\
>269 \\
>531 \\
>1094 \\
>146 \\
<0 \cdot 255 \\
>56 \cdot 9 \\
>467\end{array}$ & $\begin{array}{l}2 \\
2 \\
2 \\
2 \\
2 \\
2 \\
2 \\
2 \\
2 \\
2 \\
2 \\
2 \\
2 \\
2 \\
2 \\
2 \\
2 \\
2 \\
2 \\
2 \\
2\end{array}$ & $\begin{array}{l}4 \cdot 7 \\
4 \cdot 7 \\
4 \cdot 7 \\
4 \cdot 7 \\
4 \cdot 7 \\
4 \cdot 7 \\
4 \cdot 7 \\
4 \cdot 7 \\
4 \cdot 7 \\
4 \cdot 7 \\
4 \cdot 7 \\
4 \cdot 7 \\
4 \cdot 7 \\
4 \cdot 7 \\
4 \cdot 7 \\
5 \cdot 1 \\
4 \cdot 7 \\
4 \cdot 7 \\
5 \cdot 1 \\
4 \cdot 7 \\
4 \cdot 7\end{array}$ & $\begin{array}{r}7 \\
8 \\
4 \\
5 \\
3 \\
4 \\
7 \\
8 \\
3 \\
9 \\
6 \\
8 \\
7 \\
0 \\
18 \\
6 \\
1 \\
1 \\
1 \\
4 \\
13\end{array}$ & $\begin{array}{r}18 \cdot 9 \\
21 \cdot 6 \\
10 \cdot 8 \\
13 \cdot 5 \\
8 \cdot 1 \\
10 \cdot 8 \\
18 \cdot 9 \\
21 \cdot 6 \\
8 \cdot 1 \\
24 \cdot 3 \\
16 \cdot 2 \\
21 \cdot 6 \\
18 \cdot 9 \\
48 \cdot 6 \\
17 \cdot 1 \\
2 \cdot 7 \\
2 \cdot 7 \\
2 \cdot 7 \\
10 \cdot 8 \\
35 \cdot 1\end{array}$ & $\begin{array}{l}\text { NS } \\
<0.05 \\
\text { NS } \\
\text { NS } \\
\text { NS } \\
\text { NS } \\
\text { NS } \\
<0.05 \\
\text { NS } \\
<0.05 \\
\text { NS } \\
<0.05 \\
\text { NS } \\
\text { NS } \\
<0.00001 \\
\text { NS } \\
\text { NS } \\
\text { NS } \\
\text { NS } \\
\text { NS } \\
<0.001\end{array}$ \\
\hline $\begin{array}{l}\text { Blood: } \\
\text { Creatinine/serum } \\
\beta_{2}-\mathrm{m} / \text { serum } \\
\text { Sialic acid/plasma } \\
\text { Sialic acid/RBC } \\
\text { AB binding/RBC } \\
\text { Anti-GBM/serum }\end{array}$ & $\begin{array}{l}>11.9 \\
>2.16 \\
<495 \\
<22.5 \\
<166 \\
>38.7\end{array}$ & $\begin{array}{l}2 \\
2 \\
2 \\
1 \\
1 \\
2\end{array}$ & $\begin{array}{l}4 \cdot 7 \\
4 \cdot 7 \\
4 \cdot 7 \\
2 \cdot 3 \\
2 \cdot 3 \\
4 \cdot 7\end{array}$ & $\begin{array}{l}1 \\
6 \\
5 \\
6 \\
3 \\
2\end{array}$ & $\begin{array}{r}2 \cdot 7 \\
16 \cdot 2 \\
13 \cdot 5 \\
16 \cdot 2 \\
8 \cdot 1 \\
5 \cdot 4\end{array}$ & $\begin{array}{l}\text { NS } \\
\text { NS } \\
\text { NS } \\
\text { NS } \\
\text { NS } \\
\text { NS }\end{array}$ \\
\hline
\end{tabular}

^Fisher's exact test.

+For units see table 3 and for abbreviations see subjects and methods section.

${ }_{+}^{+}$For $\mathrm{PGE}_{2}$ and kallikrein $\mathrm{n}=39$.

$\S$ For $\mathrm{PGE}_{2} \mathrm{n}=35$.

All the markers of nephrotoxicity were standardised for the determinants unrelated to Cd exposure (see table 2). Standardisation was based on the mean of the total population.

A positive association was found between Cd-B and 6-keto-PGF ${ }_{1 x}$ and $\mathrm{PGE}_{2}$ concentrations in urine. Concentration of sialic acid in urine was positively related to Cd-B whereas sialic acid concentration in plasma and in RBC membranes showed an inverse relation with $\mathrm{Cd}-\mathrm{B}$ and $\mathrm{Cd}-\mathrm{U}$ respectively. A positive association of $\mathrm{Cd}-\mathrm{U}$ with $\beta_{2}-\mathrm{m}$, but not creatinine concentrations, in serum was also found. Eight parameters were significantly correlated with the duration of exposure in the group exposed to $\mathrm{Cd}$-namely, albumin, transferrin, IgG, $\beta_{2}$-m, RBP, $\mathrm{NAG}$, and IAP concentrations in urine, and $\beta_{2}-\mathrm{m}$ in serum.

After standardisation for determinants unrelated to exposure to $\mathrm{Cd}$ (including crt-U), $\mathrm{Cd}$ workers showed on average a significantly higher urinary excretion of transferrin, BB50, BBA, IAP, 6-keto$\mathrm{PGF}_{1 x}, \mathrm{PGE}_{2}$, and sialic acid. A significant increase in $\beta_{2}-\mathrm{m}$ in serum was also found whereas crt-S (serum) was slightly diminished (table 3 ). The comparison of prevalences of abnormal values between the two cohorts (table 4) showed a pattern that was consistent with that found for the mean values in table 3 . Tables 5 and 6 and figs 1 and 2 show dose-effect and doseresponse relations. They were established by using as landmarks the concentrations of 2 and $10 \mu \mathrm{g} / \mathrm{l}$ for $\mathrm{Cd}-\mathrm{B}$ and 2 and $10 \mu \mathrm{g} / \mathrm{g}$ creatinine for Cd-U. Regarding Cd- $U$, which is mainly a reflection of the body burden of $\mathrm{Cd}$, a significant increase in the mean values or the prevalences of abnormal values was found for the highest exposure group (Cd-U $>10 \mu \mathrm{g} / \mathrm{g}$ creatinine) for all markers measured in urine, except IgG, TNAP, fibronectin, $\mathrm{PGE}_{2}, \mathrm{PGF}_{2 x}, \mathrm{TXB}_{2}$, and kallikrein. For 6-keto-PGF ${ }_{1 x}$, the increase was already significant in the group with Cd-U between 2 and $10 \mu \mathrm{g} / \mathrm{g}$ creatinine. The rise of $\mathrm{PGE}_{2}$ in urine, by contrast, was not dose related as it reached statistical significance only in the intermediate exposure group. It should be noted, however, that two high values had to be discarded in the group with $\mathrm{Cd}-\mathrm{U}$ above 
Table 5 Mean values of urinary and bloodborne markers of nephrotoxicity as a function of $C d-U$ ( $\mu g / g$ creatinine)

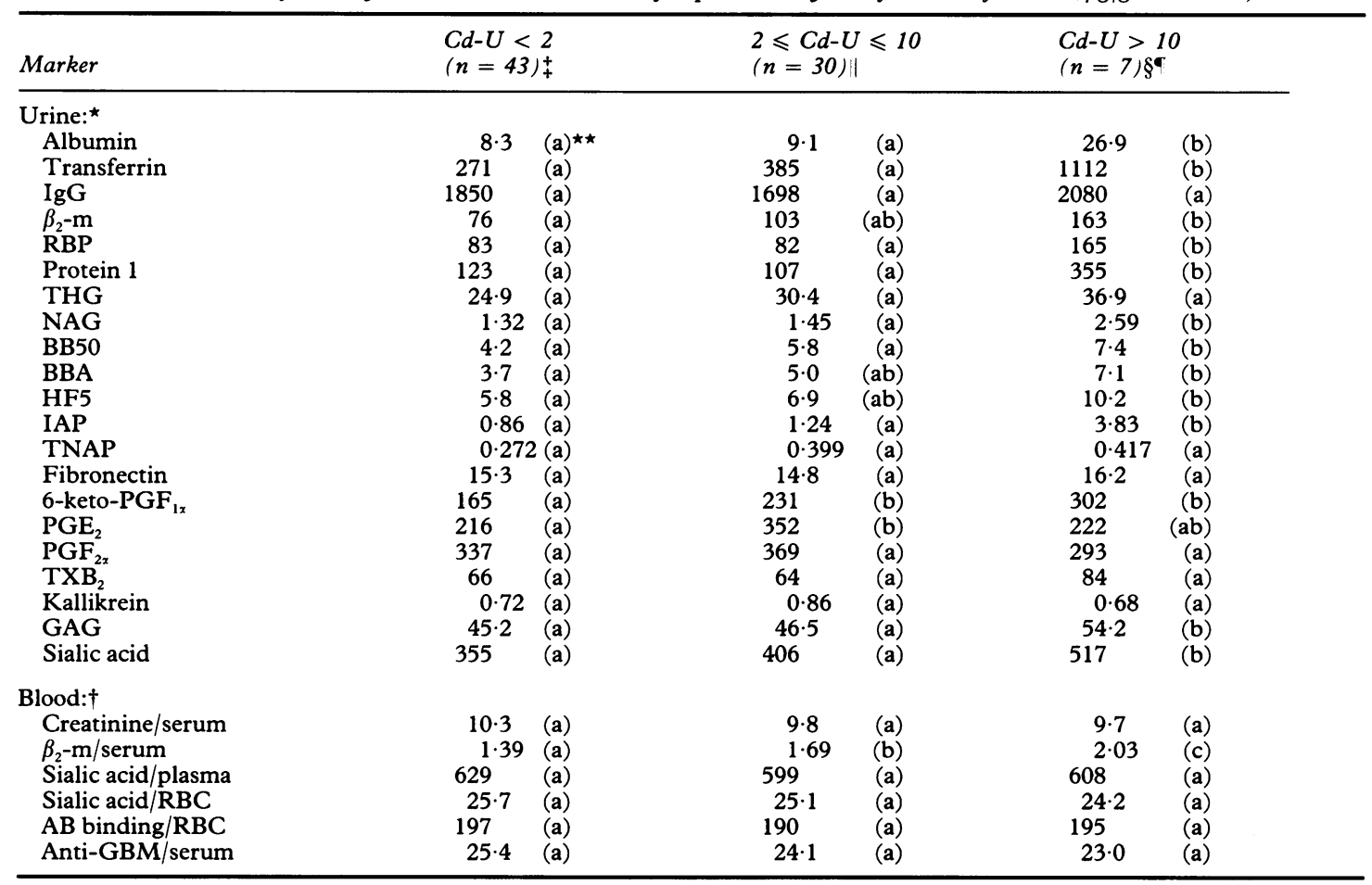

${ }^{\star}$ Geometric means; †Arithmetic means.

$\ddagger$ For $\mathrm{PGE}_{2}$ and kallikrein $\mathrm{n}=39$.

$\S$ For $\mathrm{PGE}_{2} \mathrm{n}=5$.

| 9 Average duration of $\mathrm{Cd}$ exposure was $9 \cdot 7$ and $17 \cdot 9$ years respectively.

$\star \star M$ Means with the same letter do not differ significantly (Duncan's test).

For units see table 3 and for abbreviations see subjects and methods section.

All the markers of nephrotoxicity were standardised for the determinants unrelated to Cd exposure (see table 2). Standardisation was based on the mean of the total population.

$10 \mu \mathrm{g} / \mathrm{g}$ creatinine because of suspected seminal contamination. Of the bloodborne parameters, only serum $\beta_{2}$-m concentrations showed changes related to $\mathrm{Cd}-\mathrm{U}$ (see table 5 and fig 1 ).

As a general rule, the dose dependence of renal effects is less evident when the classification is based on $C d-B$, which is not surprising as this parameter mainly reflects recent exposure to the metal. A noteworthy finding, however, is that both urinary $\mathrm{PGE}_{2}$ and 6-keto-PGF ${ }_{1 x}$ show significant dose-effect or response relations with Cd-B (see table 6 and fig 2).

A logistic regression model was applied to the exposed group to better delineate the dose-response relations between the renal variables and Cd-B, $\mathrm{Cd}-\mathrm{U}$, or duration of exposure. For $\mathrm{Cd}-\mathrm{U}$, however, because of the high sensitivity of some markers, this analysis was performed by combining the exposed group and the control workers excreting more than $1 \mu \mathrm{g} \mathrm{Cd} / \mathrm{g}$ creatinine. The reference group was thus redefined as subjects with a $\mathrm{Cd}-\mathrm{U}$ value lower than
$1 \mu \mathrm{g} / \mathrm{g}$ creatinine. The 95 th or the 5 th percentile values of this group were used as upper or lower limits of normal for all parameters. Figure 3 shows the relations emerging with $\mathrm{Cd}-\mathrm{U}$, separately for plasma derived proteins, enzymes or antigens derived from the proximal tubule, and other indicators.

The most sensitive urinary markers were 6-keto$\mathrm{PGF}_{1 x}$ and sialic acid, followed by high molecular weight proteins (albumin and transferrin) together with some tubular antigens or enzymes (BBA, IAP, and NAG), then THG, and eventually low molecular weight proteins $\left(\beta_{2}-\mathrm{m}, \mathrm{RBP}\right), \mathrm{HF} 5$, and TNAP. In that sensitivity scale serum $\beta_{2}-\mathrm{m}$ appeared immediately after high molecular weight proteins.

The thresholds of $\mathrm{Cd}-\mathrm{U}$ associated with a probability of change significantly higher than in the control group ranged from $2 \cdot 3$ (6-keto-PGF 1 ) to 11 ( $\beta_{2}$-microglobulinuria) $\mu \mathrm{g} \mathrm{Cd} / \mathrm{g}$ creatinine. It is possible to distinguish three main groups of thresholds 
Table 6 Mean values of urinary and bloodborne markers of nephrotoxicity as a function of Cd-B ( $\mu \mathrm{g} / \mathrm{l})$

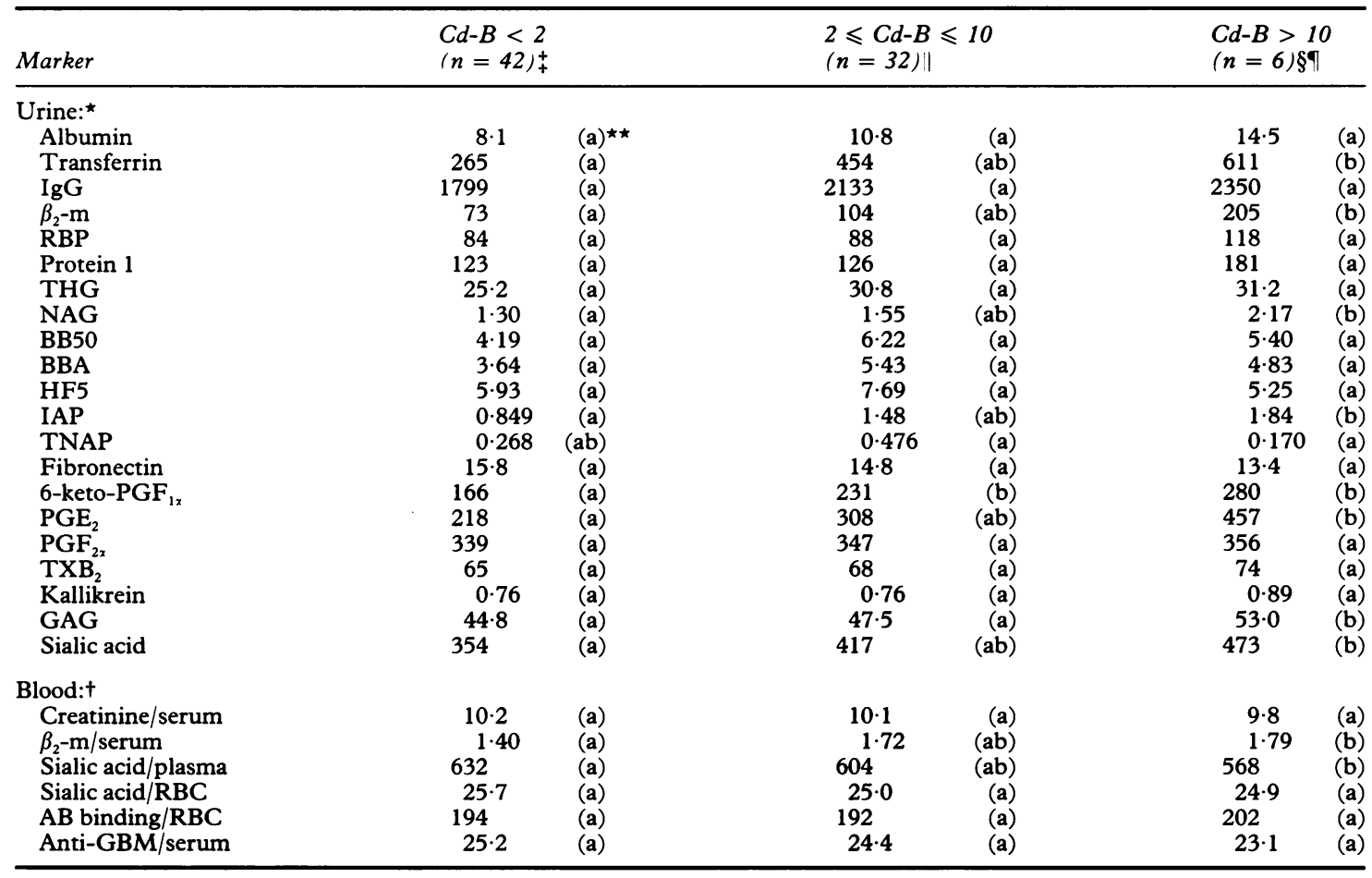

*Geometric means; † Arithmetic means.

+ For $\mathrm{PGE}_{2}$ and kallikrein $\mathrm{n}=38$.

$\S$ For $P_{\text {GE }} \mathrm{n}=4$.

| Average duration of exposure to $\mathrm{Cd}$ was 11.3 and 12.0 years respectively.

$\star \star$ Means with the same letter do not differ significantly (Duncan's test).

For units see table 3 and for abbreviations see subjects and methods section.

All the markers of nephrotoxicity were standardised for the determinants unrelated to Cd exposure (see table 2). Standardisation was based on the mean of the total population.

associated with the occurrence of renal changes: a threshold around $2 \mu \mathrm{g} \mathrm{Cd} / \mathrm{g}$ creatinine for 6 -keto$\mathrm{PGF}_{1 x}$ and sialic acid $(2.4 \mu \mathrm{g} \mathrm{Cd} / \mathrm{g}$ creatinine), around $4 \mu \mathrm{g} \mathrm{Cd} / \mathrm{g}$ creatinine for BBA, NAG, IAP, albumin, and transferrin $(3 \cdot 7,4 \cdot 0,4 \cdot 1,4 \cdot 1$, and $3.6 \mu \mathrm{g} \mathrm{Cd} / \mathrm{g}$ creatinine respectively), and a threshold around $10 \mu \mathrm{g} \mathrm{Cd} / \mathrm{g}$ creatinine for TNAP, HF5, RBP, $\beta_{2}-\mathrm{m}$, and GAG $(9 \cdot 7,10,10 \cdot 4,11.5$, and $11.5 \mu \mathrm{g} \mathrm{Cd} /$ $\mathrm{g}$ creatinine respectively). Serum $\beta_{2}-\mathrm{m}$ and urinary THG had intermediate thresholds of $6 \cdot 1$ and $7 \mu \mathrm{g} \mathrm{Cd} / \mathrm{g}$ creatinine respectively.

When the logistic regression analysis was performed with $\mathrm{Cd}-\mathrm{B}$ as the independent variable, relations similar to those shown in fig 3 were obtained with three main groups of thresholds around 2, 4, and $10 \mu \mathrm{g} \mathrm{Cd} / 1$. Three variables were also significantly related to the duration of exposure by logistic regression analysis-namely, albumin, transferrin, and IAP. For these parameters, the thresholds corres- ponding to a significant increase in the probability of change were $10.8,8.7$, and 8.3 years respectively.

Logistic regression analysis only on workers currently exposed to $\mathrm{Cd}(\mathrm{n}=26)$ and control subjects with a Cd-U higher than $1 \mu \mathrm{g} / \mathrm{g}$ creatinine produced thresholds that did not differ greatly from those mentioned, taking into account the uncertainty due to the lower number of subjects. Thresholds around $2 \mu \mathrm{g} \mathrm{Cd} / \mathrm{g}$ creatinine and that for serum $\beta_{2}-\mathrm{m}$ were unchanged, those around $4 \mu \mathrm{g} \mathrm{Cd} / \mathrm{g}$ creatinine were on average $10 \%$ lower, whereas those around $10 \mu \mathrm{g} \mathrm{Cd} / \mathrm{g}$ creatinine were $20 \%$ higher. The only threshold that was clearly different was for THG (14 instead of $7 \mu \mathrm{g} \mathrm{Cd} / \mathrm{g}$ creatinine).

\section{Discussion}

Workers examined in the present study were only moderately exposed to Cd as only a few (six or seven 

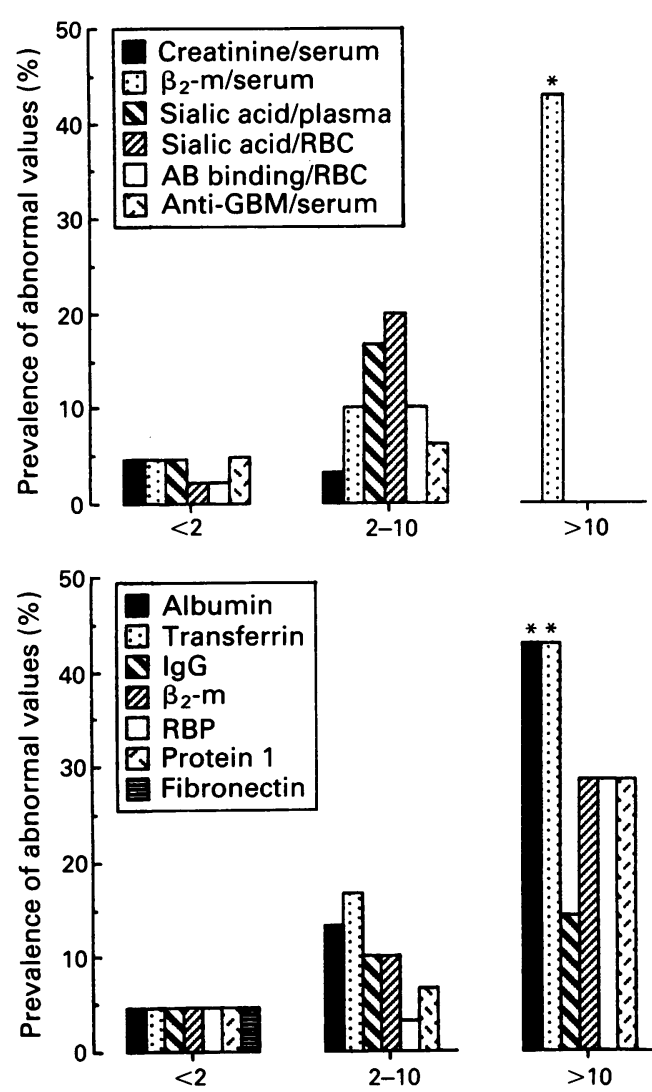
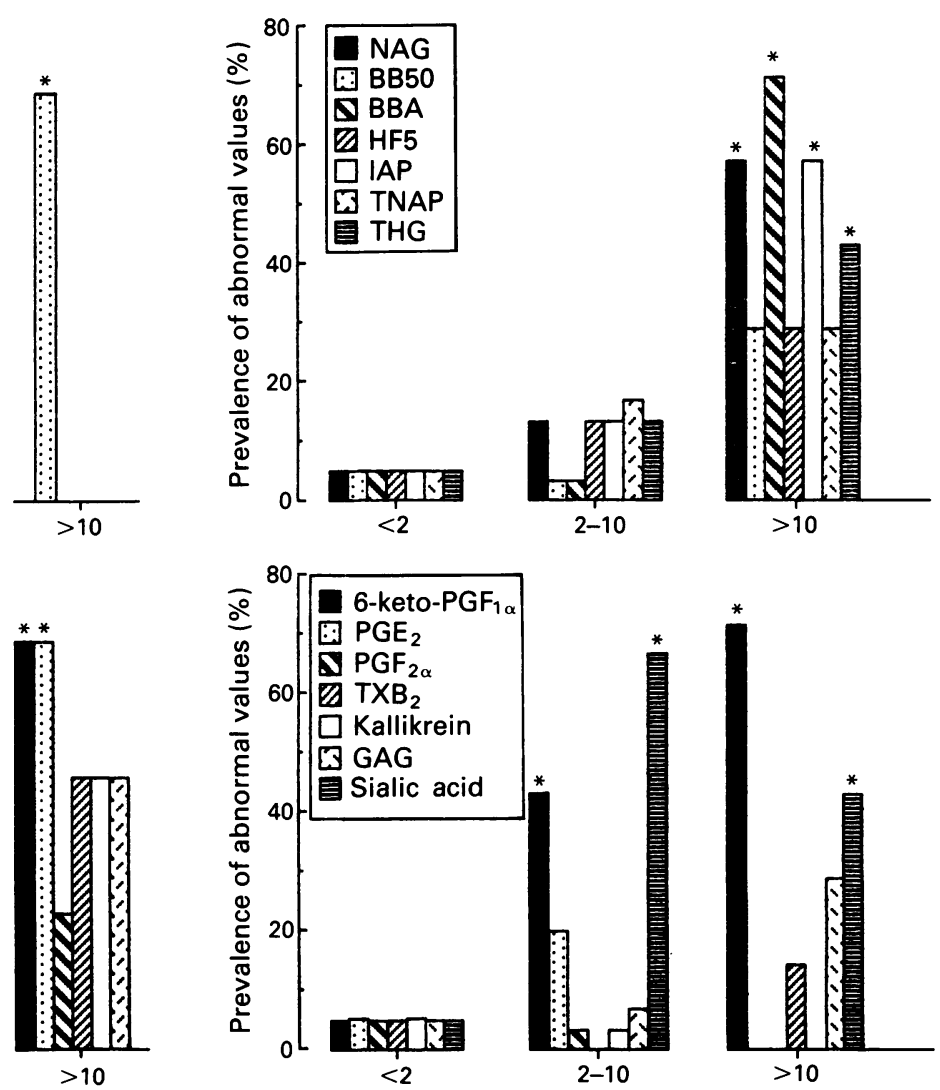

Cadmium in urine $(\mu \mathrm{g} / \mathrm{g}$ creatinine $)$

Figure 1 Prevalences of abnormal values of markers of nephrotoxicity as a function of $C d-U$ in workers exposed to Cd and their referents. Prevalences were established on the basis of the cut off values given in table 4. For group size and duration of exposure, see table 5. ^Significantly different from the group with $\mathrm{Cd}-\mathrm{U}<2 \mu \mathrm{g} \mathrm{Cd} / \mathrm{g}$ creatinine.

subjects) had Cd-B or Cd-U exceeding the previously proposed critical levels $(10 \mu \mathrm{g} \mathrm{Cd} / 1$ and $10 \mu \mathrm{g} \mathrm{Cd} / \mathrm{g}$ creatinine). ${ }^{13-15}$ Despite this moderate exposure, most potential indicators of nephrotoxicity showed alterations associated with the internal dose of Cd (table 2).

It is clear that these markers do not respond to exposure to $\mathrm{Cd}$ with the same sensitivity. Urinary 6keto-PGF $F_{1 \alpha}$ seems to be the most sensitive marker with up to $49 \%$ of abnormally increased values in the Cd group. This marker is followed by urinary sialic acid (35\% of raised values), tubular antigens or enzymes (BBA, NAG, IAP, around $20 \%$ ), and then high or low molecular weight proteins. Logistic regression analysis allowed us to derive the thresholds of Cd-U from which the probability of detecting abnormalities in these markers rises significantly. The comparatively low number of subjects and the discrete alterations of some markers (for example, $\beta_{2}-\mathrm{m}$ and RBP) preclude a very precise estimate of some thresholds. Nevertheless, this logistic regression analysis supported by the dose-response relations showed the existence of three main groups of thresholds for Cd-U; one around $2 \mu \mathrm{g} \mathrm{Cd} / \mathrm{g}$ creatinine essentially associated with biochemical changes (increased urinary 6-keto- $\mathrm{PGF}_{1 \alpha}$ and sialic acid concentrations), a second around $4 \mu \mathrm{g} \mathrm{Cd} / \mathrm{g}$ creatinine for high molecular weight proteins and some tubular antigens or enzymes (BBA, NAG), and a third one around $10 \mu \mathrm{g} \mathrm{Cd} / \mathrm{g}$ creatinine for low molecular weight proteins and other indicators; the last corresponding to the previously proposed biological threshold for Cd nephropathy. ${ }^{61315}$

These data are thus in agreement with previous studies that have reported the occurrence of some renal effects in workers excreting less than $10 \mu \mathrm{g} \mathrm{Cd} / \mathrm{g}$ creatinine. In those studies, as in the present one, the effects consisted mainly of an increased urinary 

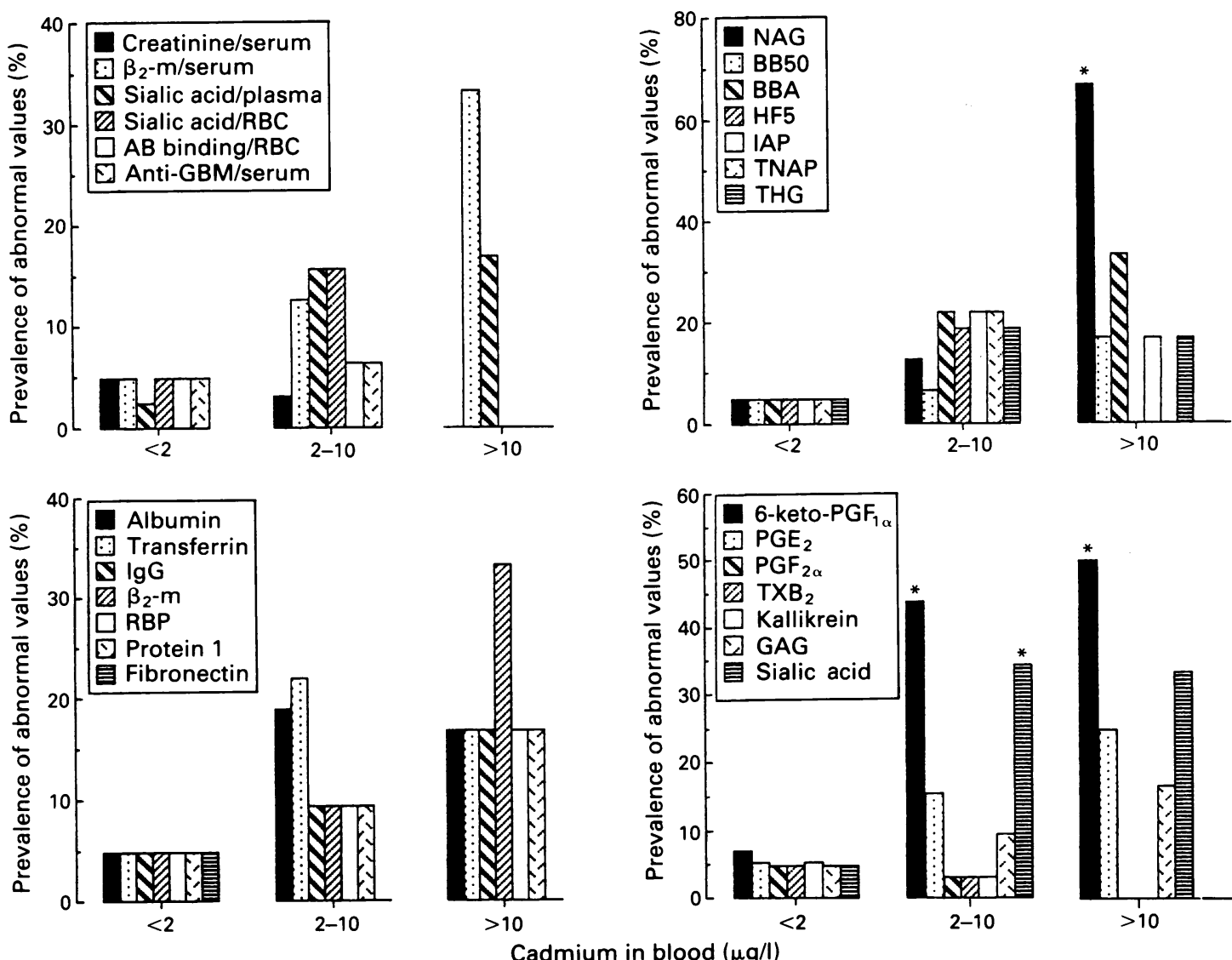

Figure 2 Prevalences of abnormal values of markers of nephrotoxicity as a function of $C d-B$ in workers exposed to $C d$ and their referents. Prevalences were established on the basis of the cut off values given in table 4. For group size and duration of exposure, see table 6. ${ }^{\star}$ Significantly different from the group with $C d-B<2 \mu g C d / l$.

excretion of tubular enzymes or antigens, although some authors have also found an increase in $\beta_{2}$ microglobulinuria (for review see ${ }^{5}$ ). The thresholds of $\mathrm{Cd}-\mathrm{U}$ derived in some of these studies are also in accordance with our estimates. For instance Mueller et $a l^{16}$ found a $10 \%$ risk of raised NAG or alanine aminopeptidase activity in urine from $\mathrm{Cd}-\mathrm{U}$ of 6.3 and $5 \mu \mathrm{g} \mathrm{Cd} / \mathrm{g}$ creatinine. Verschoor et al $^{17}$ also found that urinary NAG was significantly increased in workers with Cd-U above $5 \mu \mathrm{g} \mathrm{Cd} / \mathrm{g}$ creatinine. A somewhat lower threshold of Cd-U $(3 \mu \mathrm{g} \mathrm{Cd} / \mathrm{g}$ creatinine) was reported for NAG by Chia $e t$ al $^{21}$ but this was based on a study of female workers. Using a two phase linear regression model to estimate a threshold of cumulative exposure to $\mathrm{Cd}$ in air for the occurrence of renal changes, Mason et $^{a l^{9}}$ also noted that the inflection point of urinary NAG activity was at substantially lower $\mathrm{Cd}$ concentrations in air than that of other variables (low or high molecular weight proteins), which is in agreement with our findings for $\mathrm{Cd}-\mathrm{U}$. The question that now arises is which of these thresholds must be adopted as the maximum permissible value for occupational exposure to $\mathrm{Cd}$ ? The answer to that question depends on the health significance of the renal effects; that is, whether they are predictive or not of a progressive decline in renal function. For low molecular weight proteins, for which the threshold seems to be definitively around $10 \mu \mathrm{g} \mathrm{Cd} / \mathrm{g}$ creatinine, it is well established that their increased urinary excretion is irreversible and may lead to an exacerbation of the age related decline in the glomerular filtration rate. ${ }^{112}$ More recently, we have shown that a $\mathrm{Cd}$ body burden insufficient to cause microproteinuria (Cd-U below $10 \mu \mathrm{g} \mathrm{Cd} / \mathrm{g}$ creatinine) does not compromise the filtration reserve capacity of the kidney, and this finding was interpreted as evidence that the threshold of $10 \mu \mathrm{g} \mathrm{Cd} / \mathrm{g}$ creatinine affords an adequate protection..$^{22}$ Renal 


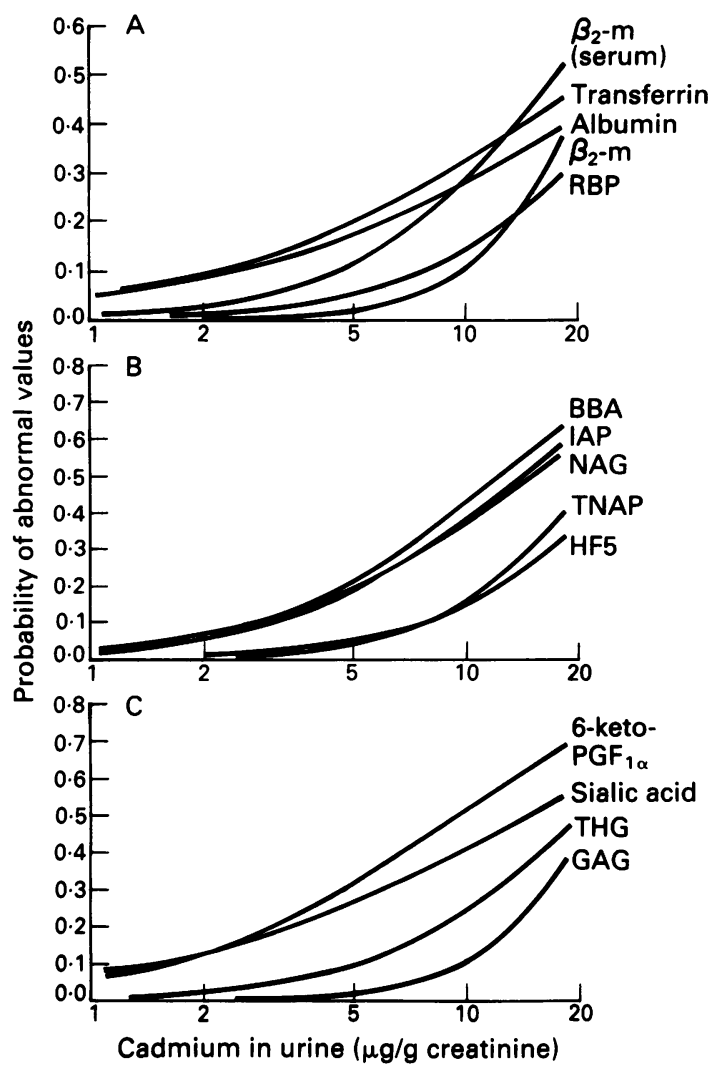

Figure 3 Probability of renal effects as a function of $C d-U$ for ( $A$ ) urinary proteins and serum $\beta_{2}-m,(B)$ enzymes or antigens in urine derived from the proximal tubule, and (C) other urinary markers. The upper limits of normal, defined as the 95th percentile of the values in control subjects with

$C d-U$ lower than $1 \mu \mathrm{g} C d / g$ creatinine were as follows (see table 3 for units ): albumin, $19 ;$ transferrin, $903 ; \beta,-m, 324$ (in serum: 2.17); $R B P, 190 ; B B A, 6 \cdot 7 ; I A P, 2.72 ; N A G$, 2.19; TNAP, 1.9; HF5, 12.6; 6-keto-PGF, 280 ; sialic acid, 501; THG , 50.1; and $G A G, 63 \cdot 2$. The $p$ values are: albumin 0.114 , transferrin $0.078, \beta_{2}-m 0.099$ (in serum 0.029), RBP 0.12, BBA 0.016, IAP 0.021, NAG 0.028, TNAP 0.068, HF5 0.094, 6-keto-PGF 10.016 , sialic acid $0.052, T H G 0.043$, and GAG 0.099. All the markers of nephrotoxicity were standardised for the determinants unrelated to Cd exposure (see table 2). Standardisation was based on the mean of the total population.

effects that occurred from a threshold of Cd-U lower than $10 \mu \mathrm{g} \mathrm{Cd} / \mathrm{g}$ creatinine consisted mostly of an increased leakage of tubular antigens or enzymes into urine. These changes, like microproteins, were related to $\mathrm{Cd}-\mathrm{U}$ as well as to $\mathrm{Cd}-\mathrm{B}$, which indicates that they are not necessarily reversible effects due to the recently absorbed $\mathrm{Cd}$. The enhanced excretion of tubular enzymes or antigens in the urine of workers exposed to Cd might be the consequence of either an exfoliation of damaged tubular cells or an increased turnover of tubular cells or some of their constituents (for example, brush border membrane antigens), or else some metabolic disturbances. Depending on the underlying mechanism some of these changes might be completely reversible and not necessarily an early sign of an irreversible tubular dysfunction.

These early tubular changes were accompanied by an increased urinary excretion of albumin and transferrin. Because in this range of $\mathrm{Cd}$ body burden the protein reabsorption capacity of tubular cells is not yet impaired, the glomerular type proteinuria may be ascribed to a loss of glomerular barrier function, resulting probably, as discussed elsewhere, ${ }^{2324}$ from a depletion of the glomerular polyanion charge. This suggests that subtle alterations of the glomerular filter may precede the onset of low molecular weight proteinuria. In that respect, it should be noted that in diabetic patients the occurrence of a persistent microalbuminuria equivalent to that found in this study is considered as a sensitive predictor of an overt clinical nephropathy. Interestingly, the serum concentration of $\beta_{2}-\mathrm{m}$ also started to increase from a threshold of urinary Cd around $6 \mu \mathrm{g} \mathrm{Cd} / \mathrm{g}$ creatinine, which reinforces the hypothesis of a slight reduction of the glomerular filtration rate preceding the occurrence of low molecular weight proteinuria.

The most remarkable finding in the present study is the very early increase of urinary $6-$ keto- $\mathrm{PGF}_{1 x}$ in workers exposed to $\mathrm{Cd}$. The sensitivity of this marker was such that a redefinition of the control group (subjects with Cd-U below $1 \mu \mathrm{g} \mathrm{Cd} / \mathrm{g}$ creatinine) was necessary to estimate a threshold of Cd-U by logistic regression analysis. It would be premature to propose a biological threshold for exposure to $\mathrm{Cd}$ on the basis of this change, for which biological significance and implications in Cd nephropathy are unknown.

It can be concluded that the recent recommendation of $5 \mu \mathrm{g} \mathrm{Cd} / \mathrm{g}$ creatinine in urine as the biological exposure limit for occupational exposure to $\mathrm{Cd}^{5}$ seems justified to prevent the earliest effects of $\mathrm{Cd}$ on the nephron, although for most of these effects the link with the subsequent development of overt $\mathrm{Cd}$ nephropathy is not established. For markers that are clinically significant because they predict an overt nephropathy (low molecular weight proteinuria), the threshold of $10 \mu \mathrm{g} \mathrm{Cd} / \mathrm{g}$ creatinine in urine has been confirmed.

It is not known whether the changes in urinary prostanoids result from a direct effect of $\mathrm{Cd}$ on their synthesis or are secondary to an effect of Cd on renal haemodynamics. Whatever the exact mechanism, an enhanced production of prostaglandins may explain the slow progression of Cd nephropathy..$^{25}$ The effects of $\mathrm{Cd}$ on renal prostanoids (enhanced urinary excretion of 6-keto-PGF ${ }_{1 x}$ and $\mathrm{PGE}_{2}$ ) are exactly opposite to those induced by lead. Because these prostanoids 
have a vasodilative action on the renal vasculature their enhanced production might partly compensate for the reduction of glomerular filtration rate resulting from the progressive loss of renal parenchyma. This compensatory mechanism, if it adds to the adaptive changes normally occurring in remnant nephrons, can further limit the capability of measurement of glomerular filtration rate to detect the loss of functional nephrons induced by $\mathrm{Cd}$.

On the other hand, prostanoids are hormones with a broad spectrum of biological activities in many organs. A recent study on cultured osteoblast like cells has suggested that $\mathrm{Cd}$ can stimulate bone resorption via an increased production of $\mathrm{PGE}_{2}{ }^{26}$ If this effect occurs in humans at exposure to $\mathrm{Cd}$ as low as that affecting the renal synthesis of prostaglandins, this observation, in agreement with the results of the Cadmibel study, ${ }^{27}$ suggests that environmental pollution by $\mathrm{Cd}$ might be a further factor contributing to bone decalcification and osteoporosis in the general population of industrialised countries.

In the present study, no reduction in RBC membrane negative charges was seen. This might be due to the degree of exposure to $\mathrm{Cd}$ that on average was - almost 10 times lower than in workers in whom this effect was previously found.$^{23}$ Significant changes in the urinary and plasma concentrations of sialic acid were found, however, which suggest a disorder in the metabolism of sialic acid. Such an effect has been previously postulated to explain the loss of RBC surface negative charges. ${ }^{23} 24$

In conclusion, the application of a large battery of sensitive indicators of nephrotoxicity has allowed us to identify three main groups of thresholds of $\mathrm{Cd}-\mathrm{U}$ for the development of incipient nephropathy: a threshold around $2 \mu \mathrm{g} \mathrm{Cd} / \mathrm{g}$ creatinine mainly associated with biochemical alterations, a threshold around $4 \mu \mathrm{g} \mathrm{Cd} / \mathrm{g}$ creatinine from which the glomerular barrier function is progressively compromised and cytotoxic effects appear in the proximal tubule, and a third threshold of $10 \mu \mathrm{g} \mathrm{Cd} / \mathrm{g}$ creatinine corresponding to the onset of proximal tubular dysfunction with increased urinary excretion of low molecular weight proteins.

\section{Appendix \\ CONVERSION OF UNITS \\ Lead $1 \mu \mathrm{g}=4.83 \mathrm{nmol}$ \\ Cadmium $1 \mu \mathrm{g}=8.90 \mathrm{nmol}$ \\ Mercury $1 \mu \mathrm{g}=4.99 \mathrm{nmol}$ \\ Creatinine $1 \mathrm{~g}=8.84 \mathrm{mmol}$}

This study was supported by the Commission of the European Communities (contract No EV4V-0173-B (GDF)), the Fonds National de la Recherche Scientifique, and the Services de la Programmation de la Politique Scientifique (Belgium). A Cárdenas was supported by a sectorial grant from the Commission of the European Communities.

Requests for reprints to: $\mathbf{R}$ Lauwerys, Industrial Toxicology and Occupational Medicine Unit, Catholic University of Louvain, 30.54 Clos Chapelle-aux-Charnץs, B-1200 Brussels, Belgium.

1 Friberg L. Proteinuria and kidney injury among workmen exposed to cadmium and metal dust. Journal of Industrial Hygiene and Toxicology 1948;30:32-6.

2 Kjellström T. Renal effects. In: Friberg L, Elinder CG, Kjellström T, Nordberg GF, eds. Cadmium and health: a toxicological and epidemiological appraisal. Vol 2. Effects and response. Boca Raton, Florida: CRC Press Inc, 1986:21-109.

3 Bernard A, Lauwerys R. Effects of cadmium exposure in humans. In: Foulkes EC, ed. Handbook of experimental pharmacology. Vol 80. Berlin: Springer-Verlag, 1986:135-77.

4 Bernard A, Lauwerys R. Early markers of cadmium nephrotoxicity: biological significance and predictive value. Toxicology and Environmental Chemistry 1990;27:65-72.

5 American Conference of Governmental Industrial Hygienists Notice of intended changes. Cadmium, methylisobutylketone and trichloroethylene. Appl Occup Environ Hyg 1991;6: 703-10.

6 Roels H, Lauwerys R, Buchet JP, et al. In vivo measurement of liver and kidney Cd in workers exposed to this metal. Environ Res $1981 ; 26: 217-40$.

7 Roels H, Lauwerys R, Dardenne AN. The critical level of Cd in human renal cortex: a reevaluation. Toxicol Lett 1983;15: 357-60.

8 Ellis KJ, Morgan WC, Zanzi I, Yazumura S, Vartsky D, Cohn SH. Critical concentration of $\mathrm{Cd}$ in human renal cortex: doseeffect studies in Cd smelter workers. $J$ Toxicol Environ Health 1981;7:691-703.

9 Mason HJ, Davison AG, Wright AL, et al. Relations between liver cadmium, cumulative exposure, and renal function in cadmium alloy workers. $\mathrm{Br} J$ Ind Med 1988;45:793-802.

10 Gompertz D, Fletcher JG, Perkins J, et al. Renal dysfunction in cadmium smelters: relation to in vivo liver and kidney cadmium concentrations. Lancet 1983;i:1185-7.

11 Roels H, Lauwerys RR, Buchet JP, Bernard AM, Vos A, Oversteyns $M$. Health significance of cadmium induced renal dysfunction: a five year follow up. $B r J$ Ind Med 1989;46: 755-64.

12 Järup L, Elinder CG. Follow-up of glomerular function in workers with cadmium-induced tubular damage. In: Cadmium in the human environment. Lyon: IARC Monograph (in press).

13 Lauwerys R, Buchet JP, Roels H, Brouwers J, Stanescu D. Epidemiological survey of workers exposed to cadmium. Arch Environ Health 1974;28:145-8.

14 Bernard A, Buchet JP, Roels H, Masson P, Lauwerys R. Renal excretion of proteins and enzymes in workers exposed to cadmium. Eur J Clin Invest 1979;9:11-22.

15 Buchet JP, Roels H, Bernard A, Lauwerys R. Assessment of renal function of workers exposed to inorganic lead, cadmium or mercury vapor. J Occup Med 1980;22:741-50.

16 Mueller PW, Smith SJ, Steinberg KK, Thun M. Chronic renal tubular effects in relation to urine cadmium levels. Nephron 1989;52:45-54.

17 Verschoor M, Herber RF, Van Hemmen J, Wibowo A, Zielhuis R. Renal function of workers with low-level cadmium exposure. Scand J Work Environ Health 1987;13:232-8.

18 Elinder CG, Edling C, Lindberg E, Kagedal B, Vesterberg O. $\beta_{2}$-microglobulinuria among workers previously exposed to Cd: follow-up and dose-response analysis. Am J Ind Med 1985;8:553-64

19 Cárdenas A, Roels H, Bonard AM, et al. Markers of early renal changes induced by industrial pollutants. I Application to workers exposed to mercury vapour. $\mathrm{Br} J$ Ind Med 1993; 50:17-27.

20 Cárdenas A, Roels H, Bonard AM, et al. Markers of early renal changes induced by industrial pollutants. II Application to workers exposed to lead. Br J Ind Med 1993;50:28-36.

21 Chia KS, Ong (iN, Fendo G. Renal tubular function of workers exposed to low levels of cadmium. Br. I Ind Med 1989;46: $165-70$. 
22 Roels HA, Lauwerys RR, Bernard AM, Buchet JP, Vos A, Oversteyns $M$. Assessment of the filtration reserve capacity of the kidney in workers exposed to cadmium. $\mathrm{Br} J$ Ind Med 1991;48:365-74.

23 Bernard AM, Ouled Amor A, Lauwerys RR. Decrease of erythrocyte and glomerular membrane negative charges in chronic cadmium poisoning. $\mathrm{Br} J$ Ind Med 1988;45:112-5.

24 Cárdenas A, Bernard AM, Lauwerys R. Disturbance of sialic acid metabolism by chronic cadmium exposure and its relation to proteinuria. Toxicol Appl Pharmacol 1991;108:547-58.

25 Roels H, Djubgang J, Buchet JP, Bernard A, Lauwerys R.
Evolution of cadmium-induced renal dysfunction in workers removed from exposure. Scand $J$ Work Environ Health 1982;8:191-200.

26 Suzuki Y, Morita I, Ishizaki Y, Yamane Y, Murota S. Cadmium stimulates prostaglandin $\mathrm{E}_{2}$ synthesis in osteoblast-like cells, MC3T3-E1. Biochim Biophys Acta 1989;1012:135-9.

27 Staessen J, Amery A, Bernard A, et al. Effects of exposure to cadmium on calcium metabolism: a population study. $\mathrm{Br} J$ Ind Med 1991;48:710-4

Accepted 2 March 1992

\section{Vancouver style}

All manuscripts submitted to the $B r J$ Ind Med should conform to the uniform requirements for manuscripts submitted to biomedical journals (known as the Vancouver style).

The $\mathrm{Br} J$ Ind Med, together with many other international biomedical journals, has agreed to accept articles prepared in accordance with the Vancouver style. The style (described in full in $\mathrm{Br}$ Med J, 24 February 1979, p 532) is intended to standardise requirements for authors.

References should be numbered consecutively in the order in which they are first mentioned in the text by Arabic numerals above the line on each occasion the reference is cited (Manson ${ }^{1}$ confirmed other reports ${ }^{2-5} \ldots$. . In future references to papers submitted to the $B r J$ Ind Med should include: the names of all authors if there are six or less or, if there are more, the first three followed by $e t$ al; the title of journal articles or book chapters; the titles of journals abbreviated according to the style of Index Medicus; and the first and final page numbers of the article or chapter.

Examples of common forms of references are:

1 International Steering Committee of Medical Editors. Uniform requirements for manuscripts submitted to biomedical journals. Br Med J 1979;1:532-5.

2 Soter NA, Wasserman SI, Austen KF. Cold urticaria: release into the circulation of histamine and eosino-phil chemotactic factor of anaphylaxis during cold challenge. N Engl J Med 1976;294:687-90.

3 Weinstein L, Swartz MN. Pathogenic properties of invading micro-organisms. In: Sodeman WA Jr, Sodeman WA, eds. Pathologic physiology: mechanisms of disease. Philadelphia: W B Saunders, 1974:457-72. 